\title{
ENO2 Negative
}

National Cancer Institute

\section{Source}

National Cancer Institute. ENO2 Negative. NCI Thesaurus. Code C162053.

An indication that ENO2 expression has not been detected in a sample. 